\title{
Eksistensi Qanun Nomor 9 Tahun 2008 Dalam Penyelesaian Tindak Pidana Penganiayan Ringan Di Kota Langsa
}

\author{
Wahyu Ramadhani \\ Universitas Sains Cut Nyak Dhien \\ wahyu_ramadhani95@yahoo.com
}

\begin{abstract}
The existence of the village as an MHA (customary villagers), is in accordance with Article 18B paragraph (2) of the 1945 Constitution. The problem is, what are the traditional rights of indigenous peoples in the empirical level of customary law, effectiveness of conduct, Qanun Number 9 of 2008 in the process of applying and implementing qanun No. 9 of 2008 in the Langsa City District area, in resolving adat cases was clearly deemed ineffective. Where in its application Qanun No. 9 of 2008 has not provided the maximum contribution in solving various problems in the Langsa City community, especially with regard to adat criminal cases. There are a number of customary criminal cases that have been resolved but have not yet given maximum contribution to the settlement. The discussion method that I will use in this study is a qualitative method. Qualitative Method is the study of various studies and collections of various types of empirical material, such as case studies, personal experiences, introspective recognition, life stories, interviews, artifacts, various texts and cultural productions, observations, history, interactional, and various visual texts. Various empirical study materials are presented in the details of the problem at various moments and various meanings and various individual lives of descriptive analysis methods. The results of the study found that, First: The pattern of the application of the fostering of customary life and customs in resolving customary criminal cases in the District of Kota Sigli has not necessarily guided by the Qanun, so it has not yet made a maximum contribution. Second: The effectiveness of the effectiveness of Qanun Number 9 Year 2008 in resolving customary criminal cases in Langsa City District can be seen from the size of the process and the verdict is not effective. In conclusion, the customary court in resolving a case must always be guided by Qanun Number 9 of 2008 in order to obtain a legal provision so as to make the community live in comfort
\end{abstract}

Keywords: Criminal detention, settlement, customary.

\begin{abstract}
Abstrak
Eksistensi gampong sebagai MHA, sudah sesuai dengan Pasal 18B ayat (2) UUD 1945. Masalahnya, apa saja dan bagaimana hak-hak tradisonal masyarakat hukum adat wujud dalam tataran empirik Pidana Adat, Efektifitas Keberlakuan, Qanun Nomor 9 Tahun 2008 Dalam proses penerapan serta pelaksanaan qanun Nomor 9 tahun 2008 di wilayah Kecamatan Kota Langsa, dalam menyelesaikan kasus adat jelas dinilai belum efektif. Dimana dalam penerapannya Qanun Nomor 9 tahun 2008 belum memberikan kontribusi yang maksimal dalam menyelesaikan berbagai
\end{abstract}


persoalan di masyarakat Kecamatan Kota Langsa, khususnya menyangkut dengan perkara pidana adat. Terdapat beberapa kasus pidana adat yang diselesaikan namun belum memberikan kontribusi yang maksimal dalam penyelesaiannya. Adapun metode pembahasan yang akan penulis gunakan dalam penelitian ini adalah metode kualitatif. Metode Kualitatif adalah kajian berbagai studi dan kumpulan berbagai jenis materi empiris, seperti studi kasus, pengalaman personal, pengakuan introspektif, kisah hidup, wawancara, artifak, berbagai teks dan produksi cultural, pengamatan, sejarah, interaksional, dan berbagai teks visual. Berbagai bahan kajian empiris itu disajikan dalam rincian persoalan di berbagai momen dan berbagai pemaknaan dan berbagai kehidupan individualmetode deskriptif analisis. Hasil penelitian ditemukan bahwa, Pertama: Pola penerapan pembinaan kehidupan adat dan adat istiadat dalam menyelesaikan kasus pidana adat di Kecamatan Kota sigli belum sepenunya berpedoman kepada Qanun, sehingga belum memberikan kontribusi yang maksimal. Kedua: Efektifitas keberlakuan Qanun Nomor 9 Tahun 2008 dalam menyelesaikan perkara pidana adat di Kecamatan Kota Langsa dilihat dari ukuran proses dan putusannya tidak efektif. Kesimpulannya, peradilan adat dalam menyelesaikan suatu perkara harus selalu berpedoman pada Qanun Nomor 9 Tahun 2008 guna untuk memperoleh suatu ketetapan hukum sehingga membuat masyarakat hidup dalam kenyaman.

Kata Kunci : pidana ringan, penyelesaian, adat

\section{A. PENDAHULUAN}

Indonesia adalah Negara Hukum (rechtstaat) sebagaimana diatur dalam pasal 1 ayat (3) Undang-Undang Dasar 1945. Sebagai Negara Hukum Indonesia sangat menjunjung tinggi persamaan hak di depan hukum dan asas kepastian hukum. Di negara Indonesia terdapat hukum publik dan privat. Hukum Pidana adalah termasuk hukum publik dimana hukum pidana tersebut membahas tentang permasalahan kejahatan yang melibatkan Negara melalui aparatur Negara seperti polisi, jaksa, hakim untuk ikut campur demi penegakan hukum.

Didalam hukum pidana yang sering disebut hukum materil yang termuat dalam Kitab Undang-Undang Hukum Pidana (KUHP) tersebut mengatur diantaranya tentang peraturan umum, tindak pidana kejahatan dan tindak pidana pelanggaran. Tindak pidana kejahatan itu terbagi menjadi dua yaitu tindak pidana berat dan tindak pidana ringan. Tindak pidana ringan khususnya untuk didaerah provinsi aceh proses penyelesaiannya mengedepankan dengan cara bermusyawarah demi terciptanya sebuah penyelesaian perdamaian, seperti yang telah diatur 
didalam pasal 13 qanun nomor 9 tahun 2008 tentang Pembinaan Kehidupan Adat dan Adat Istiadat Terhadap Tindak Pidana Penganiayaan Ringan.

Aceh adalah salah satu provinsi di Indonesia yang sangat menjunjung tinggi persamaan hak di depan hukum dan hukum adat istiadat dalam penyelesaian sengketa/perselisihan dimasyarakatnya. Hal ini terlihat dengan masih berfungsinya institusi-institusi adat di tingkat gampông atau mukim. Undang-undang nomor 5 tahun 1975 berusaha menghilangkan fungsi mukim, namun keberadaan Imum Mukim di Aceh masih tetap diakui dan berjalan sampai sekarang. Hukum adat di Aceh tetap masih memegang peranan dalam kehidupan masyarakat.

Pada umumnya penyelenggaraan Peradilan Adat Aceh dilakukan oleh Lembaga Gampoeng dan Mukim, hal yang sama berlaku untuk seluruh Aceh dalam penyelesaian sengketa adat. Hanya saja dibeberapa daerah tertentu, seperti Aceh Tamieng dan Aceh Tengah, mereka menggunakan istilah lain. Namun fungsinya tetap sama yaitu sebagai lembaga penyelesaian sengketa atau perkara adat. Badan atau lembaga penyelenggara Peradilan Adat Aceh tingkat Gampoeng/Mukim sebagai berikut;

a) Keuchik/Geuchik merupakan pemimpin masyarakat, yang dipilih secara demokrasi/langsung oleh rakyatnya menurut Undang-Undang Nomor 5 Tahun 1979, yang menurut Peraturan Daerah Nomor 6 Tahun 1982, masa jabatannya berlaku tujuh tahun, atau nama lain (sebagai ketua sidang);

b) Tuha Peuet adalah sebuah lembaga yang di Aceh berfungsi sebagai Dewan Empat yang anggota-anggotanya, baik masing-masing maupun bersamasama mengambil tanggung jawab tugas-tugas pemerintahan umum sebagai sebuah dewan yang mendampingi uleebalang dalam pelaksanaan tugas sehari-hari, atau nama lain (sebagai anggota);

c) Imeum Meunasah atau nama lain (sebagai anggota); d) Ulama adalah waraasatul ambiya, maka seyogiyanya fatwa dan peran ulama perlu direaktualkan dan direfungsikan pada posisinya sebagai pengayom dan penyuluh ummat, dalam hal ini penyuluh masyarakat Aceh. Sikap seperti ini penting untuk menjaga dan membangun Aceh yang bermartabat, Cendikiawan, Tokoh Adat atau nama lain (sebagai anggota);

d) Sekretaris Gampoeng (sebagai panitera);

e) Ulee Jurong (sebagai penerima laporan awal); 
Keberadaan Peradilan Adat, adalah suatu lembaga Musyawarah Adat/Adat Meusapat yang berfungsi melakukan tugas-tugas dan kewenangan untuk mengadili / menyelesaikan sengketa/perkara yang terjadi dalam masyarakat secara damai untuk membangun keseimbangan (equalibrium), sehingga masyarakat menjadi rukun, damai, dan sejahtera.

Para penyelenggara peradilan adat sebagaimana di jelaskan di atas tidak ditunjuk atau diangkat "secara resmi”, tetapi karena jabatannya sebagai Keuchik, Imeum Meunasah, Tuha Peuet, dan Ulee Jurong maka mereka secara otomatis menjadi para penyelenggara Peradilan Adat juga dan mereka secara resmi menjadi penyelenggara adat yang dipercayai oleh masyarakat.

Pada saat ini, keanggotaan peradilan adat tidak terbatas pada kaum lelaki, tetapi juga harus melibatkan kaum perempuan. Mereka terlibat dalam proses penyelenggaraan peradilan adat melalui jalur Tuha Peuet dimana salah satu unsur Tuha Peuet harus ada wakil dari perempuan.

Ditingkat Aparatur pemerintah yang berada ditingkat desa atau gampong itu dipimpin oleh Keuchik/geuchik. Keuchik adalah Kepala Badan Eksekutif Gampoeng dalam penyelengaraan Pemerintahan Gampoeng yang dipilih oleh masyarakat secara demokrasi yang bertujuan untuk memimpin dan menjadi kepala desa serta dapat menyelesaikan setiap permasalahan yang ada didalam desa atau gampong, sehingga segala permasalahan, dapat diselesaikan oleh geuchik dengan di bantu oleh aparat desa lainnya demi menciptakan masyarakat yang damai dan tenteram.

Dalam menyelesaikan permasalahan yang ada didalam masyarakat, geuchik selaku pemimpin tertinggi selain, harus melakukan koordinasi dengan seluruh Aparat Desa/Gampong, geuchik juga harus melakukan koordinasi dengan Kepolisian Negara RI setempat demi terciptanya tatanan bernegara yang baik.

Qanun Nomor 9 Tahun 2008 Tentang Pembinaan Kehidupan Adat dan Adat Istiadat didalam pasal 13 ayat (1),(2) dan (3) mengatur tentang jenis-jenis Sengketa/perselisihan adat yang terjadi di Gampong/desa dan cara penyelesaiaannya yaitu aparat penegak hukum memberikan kesempatan agar 
sengketa/perselisihan diselesaikan terlebih dahulu secara adat di Gampong atau nama lain.

Hak-hak adat masyarakat dari segi historis, pada umumnya menggunakan hukum adat masing-masing, yang dijiwai oleh nilai-nilai hukum Islam melalui fungsi meunasah, sehingga betapapun perkembangan sosiologis, sistem politik dan ketatanegaraaan, namun nilai-nilai budaya adat masih melekat dan menjiwai masyarakat. Sebagai masyarakat bangsa tentunya juga menerima nasib yang sama disaat hukum Nasional berlaku, dengan sendirinya sendi-sendi hukum adat menjadi tergeser dan tak berdaya.

Penerapan Undang-Undang Nasional seperti Undang-Undang Pokok Agraria (UUPA) Nomor 5 Tahun 1960, Undang-Undang Nomormor 32 Tahun 2004 tentang Pemerintah Daerah, Peraturan Pemerintah Republik Indonesia nomor 72 tahun 2005 tentang desa, telah memberi wewenang yang lebih luas kepada Pemerintah Daerah untuk lebih banyak mengurusi soal-soal wewenang dan tanggung jawab kemasyarakatan dengan alasan otonomormi daerah. Akibatnya urusan-urusan kemasyarakatan yang semula banyak dilaksanakan oleh masyarakat adat menjadi terpinggirkan bahkan hilang sama sekali.

Melalui Qanun Nomor 9 Tahun 2008 tentang Pembinaan Kehidupan Adat dan Adat Istiadat, meunasah mulai difungsikan kembali sebagai tempat musyawarah dan tempat menyelesaikan sengketa/perkara, yaitu tercantum dalam pasal 14 ayat (4) yang berbunyi "Sidang musyawarah penyelesaian sengketa/perselisihan dilaksanakan di Meunasah atau nama lain pada tingkat Gampong atau nama lain dan di Mesjid pada tingkat Mukim atau tempat-tempat lain yang ditunjuk oleh Keuchik/Geuchik atau nama lain dan Imeum Mukim atau nama lain".

Fungsi utama Meunasah adalah sebagai tempat musyawarah berbagai keperluan, membahas dan menemukan solusi terhadap masalah yang timbul, karena itu Meunasah merupakan tempat Rapat Dewan Meusapat, Rapat Dewan Meupakat, Rapat Tuha Peut, Rapat Tuha Lapan, dan Rapat Umum dari musyawarah 
melahirkan fungsi Meunasah menjadi otoritas, kewenangan dan tanggung jawab untuk mengendalikan segala tatanan kehidupan Gampong.

Selain itu Meunasah juga berfungsi menjalankan tugas-tugas peradilan dan menemukan hukum untuk digunakan pada tingkat Desa/Gampoeng, yang bersumber dari fungsionaris perangkat Gampoeng, yaitu Keuchik, Teungku Sagoe, Tuha Peut, Tuha Lapan, Tokoh-tokoh Adat dan berbagai cerdik pandai lainnya yang berwibawa/kharismatik, berkedudukan, berilmu, bahkan berharta sebagai prasyarat penghargaan dari masyarakatnya. Mereka mempunyai kemampuan dalam menggali dan menemukan nomorrma-nomorrma hukum adat untuk keperluan penyelesaian sengketa itu sendiri yang tergambar dalam pepatah adat:

Meulugot oen padee mеuриe ciceim,oh ji khem mеupu le bahsa,meunka muemet oen kayee ka meukri angen, meutho ie meupu eungkoet. Meulugot oen padee теирие ciceim (jenis burung ditandai dengan tersoyoknya daun padi), oh jikhem meupue bahsa (waktu tertawa ketahuan bahasanya), meunka muemet oen kayee ka meukri angen (jika bergerak daun kayu ketahuan angin apa), maksud dari peribahasa diatas ialah hukum adat adalah hukum yang mengendap dalam masyarakat, kapan saja ada permasalahan, hukumnya akan muncul sesuai dengan kebutuhan sebagaimana dikatakan oleh:

Moch. Koesnomore tentang Ilmu Adat sebagai salah satu khazanah Ilmu Hukum Nasional yang dikutip oleh M. Syamsuddin sebagai berikut:

"Terlaksananya hukum adat secara nyata dalam masyarakat bergantung kepada para pelaksana/petugas yang merupakan penjaga dan pengawas adat itu. Disitu letak pendirian adat, bahwa segala pedoman adat yang dimuliakan itu hanya terlaksana secara baik, bilamana pengawalnya mempunyai persyaratan-persyaratan kepribadian yang ditentukan dalam melaksanakannya menjadi kenyataan isi pedoman adat yang dimuliakan itu". ${ }^{1}$

Meunasah juga berfungsi menjalankan keputusan hukum/eksekusi atas keputusan damai yang telah ditetapkan oleh penyelenggara Peradialan Adat. Penyelenggaraan eksekusi ditetapkan didepan umum dihadiri oleh seluruh masyarakat Desa/Gampoeng dan para pihak beserta keluarga dan orang-orang tua

\footnotetext{
${ }^{1}$ Moh. Koesnoe,Catatan-catatan Terhadap Hukum Adat Dewasa Ini, Airlangga University Press, Surabaya 1979, halaman 23.
} 
dari Desa/Gampoeng tersebut. Tanggung jawab eksekutor berada ditangan Keuchik/Geuchik. Dan mempermalukan Keuchik berarti mempermalukan masyarakat Gampongnya. ${ }^{2}$

Tanggung jawab masyarakat adat adalah tanggung jawab bersama, antara pemimpin dengan rakyatnya, karena itu apapun keputusan harus melalui musyawarah mufakat, untuk menjaga masyarakatnya dari aib/malu, sebagaimana pepatah Aceh: "Saboh keubeue meukeubang, ban saboh weue meuleuhob (seekor kerbau yang berlumpur, maka satu kandang kerbau juga ikut berlumpur)”.

Rapat adat Gampong dalam menyelesaikan suatu perkara harus cukup syaratsyarat hukumnya, yaitu: kalau menimbang sama berat; kalau mengukur sama panjang; tidak boleh berpihak-pihak; lurus dan benar menjadi pegangan; benar menurut kehendak adat dan syara'. Disamping itu, Meunasah memiliki kewenangan untuk membina dan mengawasi, agar semua tatanan perilaku hidup masyarakatnya dapat berfungsi sebagaimana semestinya. Prinsip keseimbangan/equilibrium ketentraman dan kedamaian hidup merupakan landasan kestabilan untuk mewujudkan kesejahteraan kehidupan individu dan keluarga. Kesejahteraan individu dan keluarga akan mampu mewujudkan kesejahteraan Gampong mereka. Pepatah "Hudep saree, matee syahid" (hidup bersama mati syahid) merupakan pegangan untuk menghadapi tantangan, menciptakan keseimbangan dan kesejahteraan, karena fungsi pengawasan menjadi tanggung jawab masyarakat secara bersama-sama dalam setiap tindakan selalu ditempuh dengan bijak dan arif.

Dalam menyelesaikan sengketa/perselisiahan Majelis Peradilan Adat Gampoeng atau Mukim tidak mengenal format/susunan sidang peradilan adat yang baku seperti susunan sidang pada Peradilan Negeri. Hanya saja biasanya Keuchik/Geuchik duduk ditengah-tengah, diapit oleh Teungku/Imeum Meunasah disebelah kanan dan Sekretaris Gampoeng disebelah kiri, dan Tuha Peut disebelah

2 Majelis Adat Aceh, Fungsi Meunasah Sebagai Lembaga (Hukum) Adat dan Aktualisasinya di Aceh, Majelis Adat Aceh Provinsi Aceh, Banda Aceh 2009. 
kiri mereka. Di depan mereka duduk para pihak dan warga masyarakat duduk dibelakang para pihak.

Administrasi Peradilan Adat juga belum dikenal format yang baku, bahkan dalam praktek peradilannya tidak dilengkapi oleh administrasi yang memadai, dan bahkan ada yang tidak menggunakan administrasi sama sekali. Namun pada zaman yang semakin modern ini, administrasi Peradilan Adat Gampoeng/Mukim semakin dibutuhkan. Pembukuan setiap peristiwa dan data yang ada harus dilakukan. Hal ini diperlukan selain untuk dokumentasi juga untuk membuktikan bahwa apa yang dilakukan benar-benar terjadi, dan juga sebagai data antisipasi terhadap pihak-pihak yang membantah dikemudian hari.

Dari uraian diatas Penulis mengambil contoh kasus yang terjadi didaerah lhokbanie kecamatan langsa kota - kota langsa, yaitu kasus perselisihan yang telah dilakukan perdamaian diperadilan adat sebagaimana menurut Pasal 13 ayat (1) huruf (m), ayat (2) dan (3) Qanun Nomor 9 Tahun 2008 yang bunyinya: "Sengketa/perselisihan adat dan adat istiadat meliputi penganiayaan ringan Penyelesaian sengketa/perselisihan adat dan adat istiadat dapat diselesaikan secara bertahap dan aparat penegak hukum memberikan kesempatan agar sengketa/perselisihan diselesaikan terlebih dahulu secara adat di Gampong atau nama lain".

Perkara tersebut telah diselesaikan oleh geuchik dan seluruh perangkat desa serta dibantu dengan pihak kepolisian setempat dengan mengutamakan azas kekeluargaan yang berakhir pada perdamaian serta terhadap pihak yang dirugikan/korban telah diberikan kompensasi sebagai ganti rugi yang diakibatkan oleh pelaku penganiayaan tersebut dan perdamaian tersebut dibuat secara tertulis bermaterai dan di tanda tangani oleh kedua belah pihak serta pihak-pihak yang mendamaikan sebagaimana tersebut diatas, tetapi kasus ini tetap dibawa kepengadilan dengan berupa laporan yang di lakukan oleh pihak yang dirugikan/korban kepada kepolisian setempat dengan alasan ketidak puasan yang diterimanya dan telah mendapat putusan yang berkekuatan hukum tetap oleh Pengadilan Negeri dengan nomor perkara dan hukuman. 
Dari kasus diatas kita dapat melihat adanya ketidak sesuaian, padahal didalam Qanun nomor 9 Tahun 2008 telah mengatur tentang penyelesaian sengketa yaitu tindak pidana penganiayaan ringan dan hasil dari pada itu adalah perdamaian sebagaimana telah penulis sebut diatas namun perkara tersebut tetap diangkat kepengadilan.

Berdasarkan uraian tersebut diatas, penulis tertarik untuk mengetahui dengan melakukan penelitian tentang sejauh mana keberadaan qanun tersebut di atas dapat menyelesaikan perkara-perkara didalam masyarakat dan dituangkan dalam karya ilmiah. Adapun permasalahan yang akan dibahas secara lebih mendalam pada penulisan ini adalah Bagaimana proses penyelesaian perkara Tindak Pidana Penganiayaan Ringan yang terjadi pada masyarakat aceh di Desa/Gampong menurut Qanun Nomor 9 Tahun 2008 Tentang Pembinaan Kehidupan Adat dan Adat Istiadat dan faktor yang menyebabkan kurang maksimalnya Penegakan Hukum Qanun Nomor 9 Tahun 2008 Tentang Pembinaan Kehidupan Adat dan Adat Istiadat terhadap penyelesaian perkara Tindak Pidana Penganiayaan Ringan di Desa/Gampong.

\section{B. Metode Penelitian}

Penelitian ini bersifat penelitian empiris, meski demikian terlebih dahulu diawali dengan penelitian normatif. Hal tersebut disebabkan tujuan akhir yang dicapai dari penelitian ini antara lain untuk mengetahui apa yang menyebabkan Qanun nomor 9 tahun 2008 Tentang Pembinaan Kehidupan Adat dan Adat Istiadat Terhadap Tindak Pidana Penganiayaan Ringan tidak berjalan dengan semestinya dan bagaimana upaya Aparatur Pemerintahan gampong dalam menyelesaikan masalah agar dapat menjalankan qanun tersebut. Oleh sebab itu, penelitian dalam rangka penyusunan karya ilmiah ini menggunakan metode penelitian yuridis normatif dan yuridis empiris, oleh karena itu penelitian ini lebih bersifat pada data skunder, sedangkan data primer (data yang diperoleh langsung dari responden) lebih bersifat sebagai pendataan. 


\section{Proses Penyelesaian Perkara Pidana Ringan Menurut Qanun Nomor 9 Tahun 2008}

Kini, kearifan lokal masyarakat gampong di Aceh dalam penyelesaian sengketa/perselisihan telah dikukuhkan secara tegas dalam Qanun Aceh Nomor 9 Tahun 2008 tentang Pembinaan Kehidupan Adat dan Adat Istiadat. Dalam Pasal 13 qanun tersebut jelas disebutkan terdapat 18 jenis sengketa/perselisihan yang dapat diselesaikan secara adat, meliputi: perselisihan dalam rumah tangga; sengketa antara keluarga yang berkaitan dengan faraidh; perselisihan antar warga; khalwat meusum; perselisihan tentang hak milik; pencurian dalam keluarga (pencurian ringan); perselisihan harta sehareukat; pencurian ringan; pencurian ternak peliharaan; pelanggaran adat tentang ternak, pertanian, dan hutan; persengketaan di laut; persengketaan di pasar; penganiayaan ringan; pembakaran hutan (dalam skala kecil yang merugikan komunitas adat); pelecehan, fitnah, hasut, dan pencemaran nama baik; pencemaran lingkungan (skala ringan); ancam mengancam (tergantung dari jenis ancaman); dan perselisihan-perselisihan lain yang melanggar adat dan adat istiadat.

Selanjutnya, ditegaskan pula bahwa penyelesaian sengketa/perselisihan adat dan adat istiadat sebagaimana dimaksud di atas diselesaikan secara bertahap (Ps 13 ayat 2). Ini maksudnya, sedapat mungkin, perkara-perkara sebagaimana dimaksudkan di atas, diselesaikan terlebih dahulu pada tingkat peradilan gampong oleh aparat gampong. Maksudnya, terhadap jenis perkara di atas tidak langsung dibawa keluar gampong untuk menyelesaikannya, baik oleh polisi atau oleh pihak lainnya. Bahkan, dalam ayat berikutnya ditegaskan lagi, bahwa Aparat penegak hukum memberikan kesempatan agar sengketa/perselisihan diselesaikan terlebih dahulu secara adat di gampong.

Perlu pula disampaikan bahwa penyelesaian permasalahan hukum yang boleh diselesaikan di gampong menurut qanun tersebut, meliputi sengketa atau perselisihan. Istilah sengketa merujuk ke kasus perdata, sedangkan istilah perselisihan merujuk ke kasus pidana. Hal ini dapat dimaklumi karena dalam 
perspektif Hukum Adat tidak mengenal pembedaan hukum pidana dan hukum perdata sebagaimana dikenal dalam Hukum Peraturan Perundang-undangan.

Dalam Qanun Aceh Nomor 4 Tahun 2003 tentang Pemerintahan Gampong, yang dijabarkan dengan Peraturan Gubernur Aceh Nomor 25 Tahun 2011 tentang Pedoman Penyelenggaraan Pemerintahan Gampong, telah ditentukan bahwa salah satu tugas dan fungsi keuchik adalah sebagai hakim gampong yang berupaya menyelesaikan permasalahan hukum terkait sengketa/perselisihan yang terjadi di dalam gampong.

Tugas keuchik melakukan peradilan adat untuk menyelesaikan sengketa/perselisihan diatur juga dalam Qanun Aceh Nomor 10 Tahun 2008 tentang Lembaga Adat. Dalam pasal 15 ayat (1) huruf j dan huruf k qanun ini dinyatakan bahwa kechik bertugas memimpin dan menyelesaikan masalah sosial kemasyarakatan dan menjadi pendamai terhadap perselisihan antar penduduk dalam gampong. Adanya ketentuan di atas, menjadi jelas bahwa ketua gampong di Aceh (kechik) memiliki kewenangan sah dan resmi yang diatur tegas dalam produk legislasi (qanun) dan dijabarkan dalam peraturan gubernur.

Dalam buku pedoman peradilan adat di Aceh, disebutkan beberapa asas dalam proses peradilan adat untuk menyelesaikan sengketa/perselisihan, yaitu : ${ }^{3}$

a. Terpercaya atau Amanah (Acceptability) Peradilan adat dapat dipercayai oleh masyarakat.

b. Tanggung Jawab/Akuntabilitas (Accountability) Prinsip ini menggarisbawahi pertanggung jawaban dari para pelaksana peradilan adat dalam menyelesaikan perkara tidak hanya ditujukan kepada para pihak, masyarakat dan negara tetapi juga kepada Allah SWT.

c. Kesetaraan di Depan Hukum/Non-diskriminasi (Equality before the law/NonDiscriminaton) Peradilan adat tidak boleh membeda-bedakan jenis kelamin, status sosial ataupun umur. Semua orang mempunyai kedudukan dan hak yang sama dihadapan adat.

\footnotetext{
${ }^{3}$ Majelis Adat Aceh dan UNDP, Pedoman Peradilan Adat di Aceh, 2008.
} 
d. Cepat, Mudah dan Murah (Accessibillity to all Citizens) Setiap putusan peradilan Gampong harus dapat dijangkau oleh masyarakat baik yang menyangkut dengan biaya, waktu dan prosedurnya.

e. Ikhlas dan Sukarela (Voluntary nature) Keadilan adat tidak boleh memaksa para pihak untuk menyelesaikan perkaranya melalui peradilan adat.

f. Penyelesaian damai/ kerukunan (Peaceful Resolution) Dalam bahasa Aceh, azas ini dikenal dengan ungkapan "Uleue bak mate ranteng ek patah”, tujuan dari peradilan adat adalah untuk menciptakan keseimbangan dan kedamaian dalam masyarakat.

g. Musyawarah/Mufakat (Consensus) Keputusan yang dibuat dalam peradilan adat berdasarkan hasil musyawarah mufakat yang berlandaskan hukum dari para pelaksana peradilan adat.

h. Keterbukaan untuk Umum (Transparency) Semua proses peradilan (kecuali untuk kasus-kasus tertentu) baik yang menyangkut pautkan penerimaan pengaduan, pemanggilan saksi, persidangan maupun pengambilan serta pembacaan putusan harus dijalankan secara terbuka.

i. Jujur dan Kompetensi (Competence/Authority) Seorang pemimpin adat tidak boleh mengambil keuntungan dalam bentuk apapun baik material maupun non material dari penanganan perkara.

j. Keberagaman (Pluralism) Peradilan adat menghargai keberagaman peraturan hukum yang terdiri dari berbagai sistem hukum adat dan berlaku dalam suatu masyarakat adat tertentu.

k. Praduga Tak Bersalah (Presumption of Innocence) Hukum adat tidak membenarkan adanya tindakan main hakim sendiri.

1. Berkeadilan (Proportional Justice) Putusan peradilan adat harus bersifat adil dan diterapkan berpedoman sesuai dengan berdasarkan parahnya perkara dan keadaan ekonomi para pihak.

Secara teknis operasional tatacara penyelesaian sengketa/perselisihan secara adat di gampong telah diatur dalam Surat Keputusan Bersama (SKB) antara Gubernur, Kapolda, dan Majelis Adat Aceh tanggal 20 Desember 2011, yang dijabarkan dengan Peraturan Gubernur Aceh Nomor 60 Tahun 2013 tentang 
Pelaksanaan Penyelesaian Sengketa/Perselisihan Adat dan Istiadat. Dalam SKB tersebut ditetapkan beberapa keputusan :

- Kesatu : Sengketa/perselisihan yang terjadi ditingkat gampong dan mukim yang bersifat ringan sebagaimana dimaksud dalam Pasal 13, Pasal 14, dan Pasal 15 Qanun Aceh Nomor 9 Tahun 2008 wajib diselesaikan terlebih dahulu melalui Peradilan Adat Gampong dan Mukim atau nama lain di Aceh.

- Kedua : Aparat Kepolisian memberikan kesempatan agar setiap sengketa/perselisihan sebagimana dimaksud dalam diktum KESATU untuk diselesaikan terlebih dahulu melalui Peradilan Adat Gampong dan Mukim atau nama lain di Aceh.

- Ketiga : semua pihak wajib menghormati penyelenggaraan Peradilan Adat Gampong dan Mukim atau nama lain di Aceh.

- Keempat : Peradilan Adat Gampong dan Mukim atau nama lain di Aceh dalam menyelesaikan dan memberikan putusan berdasarkan pada norma Hukum Adat dan adat istiadat yang berlaku di daerah setempat.

- Kelima : Persidangan Peradilan Adat Gampong dan Mukim atau nama lain di Aceh dihadiri oleh para pihak, saksi-saksi dan terbuka untuk umum, kecuali untuk kasus-kasus tertentu yang menurut adat dan kepatutan tidak boleh terbuka untuk umum serta tidak dipungut dibiaya.

- Keenam : Putusan Peradilan Adat Gampong dan Mukim atau nama lain di Aceh bersifat final dan mengikat serta tidak dapat diajukan lagi pada peradilan umum atau peradilan lainnya.

- Ketujuh : Setiap Putusan Peradilan Adat Gampong dan Mukim atau nama lain di Aceh dibuat secara tertulis, ditandatangani oleh Ketua dan Anggota Mejelis serta kedua belah pihak yang bersengketa, dan tembusannya disampaikan kepada Kepala Kepolisian Sektor (KAPOLSEK), Camat serta Majelis Adat Aceh Kecamatan.

- Kedelapan : Penyelenggaraan Peradilan Adat Gampong dan dan Mukim atau nama lain di Aceh dalam memberikan putusan dilarang menjatuhkan sanksi badan, seperti pidana penjara, memandikan dengan air kotor, mencukur rambur, 
menggunting pakaian dan bentuk-bentuk lain yang bertentangan dengan nilainilai Islami.

- Kesembilan : perkara yang diselesaikan ditingkat Mukim adalah perkara yang tidak selesai ditingkat gampong.

- Kesepuluh : Pemerintah Aceh dan Pemrintah Kabupaten/Kota membina dan mengawasi pelaksanaan Peradilan Adat Gampong dan Mukim atau nama lain di Aceh.

- Kesebelas : Kepala Kepolisian Daerah Aceh dan Ketua Majelis Adat Aceh beserta seluruh jajarannya (provinsi, kabupaten/kota) berkewajiban memberikan bimbingan, pembinaan, pengambangan dan pengawasan materi-materi Hukum Adat dan Adminitrasi Peradilan Adat sesuai dengan tatanan dan asas-asas Hukum Adat/Adat Istiadat yang berlaku pada lingkungan masyarakat setempat.

- Keduabelas : Pemerintah Aceh dan Pemerintah Kabupaten/Kota dapat membantu pembiayaan administrasi untuk penylenggaraan Peradilan Adat Gampong dan Mukim atau nama lain di Aceh sesuai kemapuan daerah.

- Ketigabelas : Majelis Peradilan Adat Gampong dan Mukim atau nama lain di Aceh dalam meyelesaikan sengketa / perselisihan berpedoman pada Qanun Aceh Nomor 9 Tahun 2008 dan Peraturan Gubernur Aceh Nomor 25 Tahun 2011 tentang Pedoman Umum Penyelenggaraan Pemerintahan Gampong.

Pola penyelesaian sengketa/perselisihan yang berbasis budaya hukum Aceh sebagaimana dikemukakan di atas, menimbulkan implikasi, disatu sisi adanya penguatan otonomi gampong dan sekaligus mengurangi beban kerja aparat penegak hukum (polisi, jaksa, hakim negara). Namun disisi lain, diperlukan adanya peningkatan kapasitas para pimpinan gampong, sehingga kearifan, kebijakan, dan kepiawaiannya dalam menyelesaikan berbagai perkara di gampong dapat memberikan rasa adil bagi para warganya.

Perlunya penguatan kapasitas bagi aparat pemerintahan gampong karena menurut Pasal 14 Qanun Aceh 9/2008 jontho Pasal 16 Pergub Aceh No 60 Tahun 2013, penyelesaian secara adat di gampong dilaksanakan oleh tokoh-tokoh adat 
yang terdiri atas: keuchik, imeum meunasah, tuha peut; sekretaris gampong, ulama, cendekiawan dan tokoh adat lainnya di gampong sesuai dengan kebutuhan.

Pada prinsipnya, sidang peradilan adat dilaksanakan di meunasah secara terbuka, tidak boleh di tempat lain, sebagaimana diatur dalam Pasal 14 ayat (4) Qanun Aceh No 9 Tahun 2008. Hal ini penting karena menyangkut dengan legalitas hasil musyawarah penyelesaian sengketa tersebut. Namun menurut Pasal 16 ayat (8) Pergub Aceh No 60 Tahun 2013, terhadap sidang musyawarah penyelesaian sengketa/perselisihan yang melibatkan perempuan dan anak, baik sebagai pelaku atau sebagai korban dilaksanakan secara tertutup di rumah salah satu pimpinan adat seperti rumah keuchik, imuem meunasah atau rumah anggota tuha peut.

Dalam Pasal 15 Qanun Aceh Nomor 9 Tahun 2008, ditentukan bahwa "tata cara dan syarat-syarat penyelesaian perselisihan/persengketaan, dilaksanakan sesuai dengan ketentuan adat setempat". Walaupun ketentuan ini sangat singkat dan tegas, namun maknanya sangat dalam dan luas. Ini merupakan salah satu khas lainnya (disamping bersifat communal) dari hukum adat yang bersifat fleksibilitas. Artinya, mengenai hukum materil dan hukum formil dalam proses penyelesaian perkara tersebut mengacu pada hukum adat setempat. Hal ini sesuai dengan pepatah adat "lain lubuk lain ikannya, lain padang lain pula belalangnya".

Berdasarkan hasil penelitian Airi Safrizal, terdapat tatacara penyelesaian sengketa / perselisihan (peukara) dan pengambilan keputusan dalam sistem Hukum Adat Aceh, yaitu meliputi: ${ }^{4}$

a. Penerimaan peukara

b. Pemberitahuan kepada Tuha Peut dan Imuem Meunasah oleh Kechik,

c. Pemanggilan dan memeriksa para pihak,

d. Kesepakatan keputusan,

e. Penegakan sanksi, berupa : sie kameeng, ija puteh, peusijuk, peng pengubatan, lakee meu'ah, dan mumat jaroe.

Dalam Pasal 16 Qanun Aceh Nomor 9 Tahun 2008 diatur mengenai jenisjenis sanksi yang dapat dijatuhkan dalam penyelesaian sengketa adat. Berkaitan

\footnotetext{
${ }^{4}$ Airi Safrizal, Ibid., Bab IV.
} 
dengan jenis sanksi, Teuku Muttaqin Mansur menjelaskan pengertian dari sanksisanksi tersebut, antara lain yaitu $:^{5}$

a. Pernyataan maaf

Pernyataan maaf ialah kata-kata permohonan maaf yang disampaikan oleh pelaku/pelanggar ataupun pihak yang tidak bersalah. Dalam praktiknya, pihak yang bersalah biasanya adalah orang yang lebih dahulu meminta maaf kepada pihak yang tidak bersalah. Kalau pihak yang tidak bersalah memaafkan, maka sengketa/perselisihan mereka selesai. Niat para pihak dalam pernyataan bukan karena ada paksaan dari perangkat peradilan adat atau tekanan dari pihak-pihak yang lain, akan tetapi pernyataan maaf itu muncul dari keiklasan hati para pihak.

b. Sayam

Sayam adalah mendamaikan. Perdamaian yang dikategorikan sebagai 'Sayam' ialah perdamaian karena melakukan tindak pidana adat. Pidana yang dikenakan sayam biasanya sengketa/perselisihan biasa yang tidak mengeluarkan darah, seperti perkelahian. Sanksi bagi pelaku yang melakukan kesalahan tersebut ialah membayar diat.

c. Diat

Menurut istilah syarak, diaat adalah harta yang wajib dibayar karena sesuatu pidana yang dilakukan terhadap nyawa atau anggota badan yang tidak mengakibatkan kehilangan nyawa. Diat ialah denda karena membunuh atau melukai seseorang

d. Denda

Pengenaan denda adat biasanya diberi kepada pelaku khalwat. Denda yang dikenakan ialah memotonfg seekor kambing. Selain denda kambing, adakalanya juga pelaku/pelanggar khalwat akan di kenakan sanksi berlapis, yaitu selain

5 Teuku Muttaqin Mansur, "Pelaksanaan Peradilan Adat Mukim di Aceh" dalam Taqwaddin, Teuku Muttaqin Mansur, dan Sulaiman Tripa dkk, Mukim di Aceh; Belajar dari Masa lalu untuk Membangun Masa Depan, Dandra Pustaka Indonesia, 2015, hal 175-181. 
denda juga dapat dikenakan sanksi di asingkan atau bahkan dicabut kartu tanda penduduk sebagai anggota masyarakat.

e. Ganti rugi

Sanksi ganti rugi biasanya dikenakan kepada pelaku/pelanggar yang melakukan pencurian ringan, seperti: pencuri buah-buahan, atau merusak tanaman orang lain. Dalam menentukan jumlah ganti rugi, selain mempertimbangkan keadaan pelaku/pelanggar dan para pihak, majelis peradilan adat juga akan meninjau lokasi dimana pelaku/pelanggar melakukan pencurian atau tempat dimana tanaman dirusak. Taksiran kerugian akan dilakukan dan berdasarkan taksiran tersebut, peradilan adat akan mengenakan denda kepada pelaku/pelanggar.

f. Hukuman dikucilkan

Sanksi dikucilkan dikenakan kepada orang yang biasanya tidak menyertai kegiatan-kegiatan di gampong, seperti gotong-royong. Gotong-royong ialah kegiatan masyarakat membersihkan kampung biasanya dilakukan pada menjelang hari-hari besar tertentu, tetapi ada pihak yang tidak ikut serta gotong royong dengan tiada alasan yang dapat di pertanggung jawabkan. Pihak yang tidak ikut serta tersebut biasanya akan dikucilkan oleh masyarakat dengan cara, seperti tidak akan menyertai jika di rumah pelangar adat tersebut akan dilaksanakan pesta, atau kanduri, atau jika anggota keluarganya mendapatkan kemalangan, maka masyarakat tidak akan datang menziarahinya.

g. Hukuman pengasingan/dicabut hak sebagai penduduk kampong Hukuman diasingkan ialah hukuman yang dijatuhkan kepada pelaku/pelanggar yang dianggap telah mengotori kampung. Biasanya dikenakan kepada pelaku khalwat atau zina. Pelaku/pelanggar baik laki-laki atau pun perempuan yang terbukti melakukan perbuatan tersebut akan diasingkan dari gampong asalnya. Setelah pelaku/pelanggar menjalani sanksi tersebut dalam masa tertentu, mereka boleh kembali lagi ke kampung asalnya.

h. Pencabutan gelar adat 
Gelaran adat ialah anugerah yang diberikan khusus kepada individu atau pun institusi yang berada di Aceh, dimiliki oleh orang aceh atau pun oleh individu yang berada di luar aceh dan institusi yang dimiliki oleh bukan orang aceh. Gelaran diberi oleh Wali Nanggroe sebagai pemangku adat di aceh. Bagaimanapun tokoh adat lain seperti panglima laot juga boleh memberikan gelaran adat kepada sesiapa yang mereka anggap mempunyai kepedulian dan pengembangan bagi nelayan di Aceh. Jika seseorang melakukan pelanggaran adat, maka gelar yang diberikan tersebut dapat dibatalkan.

Dalam Pasal 16 ayat (2) Qanun Aceh Nomor 9 Tahun 2008 tentang Pembinaan Kehidupan Adat dan Adat Istiadat, juga diatur bahwa "keluarga pelanggar adat ikut bertanggung jawab atas terlaksananya sanksi adat yang dijatuhkan kepada anggota keluarganya". Adanya ketentuan ini menunjukkan bahwa karakteristik hukum adat yang bersifat komunal, bukan individual. Sehingga, pembebanan sanksi tidak hanya merupakan tanggungjawab pribadi orang perseorangan yang melakukan sesuatu yang dapat menimbulkan sengketa atau perselisihan, tetapi juga merupakan tanggung jawab bersama keluarganya.

Penerapan sanksi diberikan sesuai dengan sengketa/perselisihan yang terjadi, kerugian dan dampak yang ditimbulkan, serta kondisi sosial ekonomi para pihak yang bersengketa/berselisih. Sanksi tersebut diberlakukan secara bertahap, sesuai kesepakatan antara para pihak dan/atau pelaku dengan Majelis Peradilan Adat. Apabila sanksi yang diputuskan oleh Majelis tidak dilaksanakan, maka majelis bersidang untuk membahas pelaksanaan sanksi yang telah dijatuhkan.

Setiap putusan majelis peradilan adat disertai dengan proses perdamaian dan pemulihan. Proses tersebut diwujudkan dalam bentuk saling memaafkan (berjabat tangan) dan/atau acara peisijuk. Majelis Peradilan Adat berkewajiban menegaskan atas perdamaian yang sudah diselesaikan, meminta para pihak dan warga masyarakat untuk tidak mengungkit-ungkit lagi persoalan yang pernah terjadi. Proses perdamaian tersebut wajib dihadiri para pihak dan pimpinan gampong.

Setiap Putusan Peradilan Adat Gampong dan Mukim atau nama lain di Aceh dibuat secara tertulis, ditandatangani oleh Ketua dan Anggota Majelis serta kedua 
belah pihak yang bersengketa, dan tembusannya disampaikan kepada Kepala Kepolisian Sektor (Kapolsek), Camat serta Majelis Adat Aceh Kecamatan. Putusan ini bersifat final dan mengikat serta tidak dapat diajukan lagi pada peradilan umum atau peradilan lainnya. Hal ini tegas dinyatakan dalam Diktum Keenam SKB Gubernur, Kapolda, dan Majelis Adat Aceh.

Pihak kepolisian sektor kecamatan terlibat secara pasif dalam proses penyelesaian sengketa / perselisihan secara adat gampong di Aceh. Aparat kepolisian dapat berperan membina dan mengawasi, sehingga putusan sanksi adat, perdamaian serta pemulihan dapat dilaksanakan sesuai hasil musyawarah.

\section{Faktor Menyebabkan Kurang Maksimalnya Penegakan Hukum Qanun Nomor 9 Tahun 2008}

Dalam proses untuk menjaga keberlangsungan hukum adat, pemerintah Aceh telah mensahkan Qanun No 9 Tahun 2008 yang bertujuan untuk menjaga keberlangsungan adat-istiadat dalam kehidupan bermasyarakat. Dengan lahirnya Qanun tersebut, diharapkan persoalan-persoalan kecil yang sering terjadi dalam kehidupan bermasyarakat dapat diselesaikan di tingkat-tingkat Gampong.

Saat ini ada keinginan kuat dari para penyelenggara peradilan adat bahwa sebaiknya penetapan putusan adat dibuat secara tertulis, karena dengan bentuk tertulis akan menambah bobot putusan itu sendiri. Di samping itu, pemantauan terhadap putusan tersebut akan lebih diawasi. Diharapkan juga agar salinan putusan tersebut disampaikan kepada yang bersangkutan (para pihak), lembaga mukim, dan pihak kepolisian. Hal ini, bertujuan agar supaya mereka mengetahui kalau suatu perkara telah diselesaikan di tingkat peradilan Gampong dan mereka tidak perlu memeriksakan kembali, kecuali dalam kasus-kasus tertentu yang memang bukan merupakan kewenangan Gampong.

Jika perkara ini di kemudian hari akan dimintakan banding, sebuah keputusan tertulis akan menjadi bukti penting dalam penentuan perkara banding. Hingga saat ini segala putusan yang dibuat oleh peradilan adat khususnya di tingkat Gampong 
masih relevan, efektif dan tetap dilaksanakan oleh para pihak yang bersengketa. Para pihak yang bersengketa merasa bahwa putusan yang diambil benar-benar sesuai dengan pertimbangan-pertimbangan adat dan tanpa meninggalkan ketentuan syariat Islam yang tetap diutamakan di Aceh.

Adapun yang menjadi parameter efektifitas berbeda-beda menurut pendapat beberapa ahli. Menurut Soerjono Soekanto hukum itu efektif dan ditaati orang karena adanya kesadaran, adanya sanksi, adanya tekanan, lingkungan sosial. Lingkungan sosial yang dimaksud sangat mempengaruhi tumbuhnya motivasi untuk menaati atau melanggar hukum adalah lingkungan terdekat dengan seseorang yaitu orang tua, teman sepermainan, dan kelompok pendidik. ${ }^{6}$ Sementara menurut Profesor Mahadi bahwa hukum adat itu efektif dan dipatuhi orang karena ada orang yang mengingatkan, meski tidak tertulis. ${ }^{7}$

Sementara dilain pihak Profesor Koesno menyebutkan bahwa hukum adat itu efektif dan dipatuhi orang karena telah memenuhi asas pantas,adil, patut dan laras. ${ }^{8}$ Namun menurut Tom. R. Tyler; orang mematuhi hukum karena Tuhan, terkait dengan wajar atau tidaknya suatu kaidah hukum yang akan dipatuhi itu. Hal itu telah diuji dengan Teori Keadilan Prosedural oleh Leventhal, dimana hasil penelitian menyebutkan baha wajar atau tidaknya hukum yang dipatuhi diukur pada tiga hal penting yaitu konsistensi, representasi, dan keakuratan. ${ }^{9}$

\section{E. KESIMPULAN}

Berdasarkan bahasan di atas, dapat disimpulan bahwa eksistensi gampong sebagai MHA, tentu sudah sesuai dengan Pasal 18B ayat (2) UUD 1945, yaitu "negara mengakui dan menghormati kesatuan-kesatuan masyarakat hukum adat beserta hak-hak tradisonalnya”. Aceh sebagai daerah istimewa dan berotonomi khusus, bersyukur mulai mengisi implementasi MHA dengan diberinya kewenangan

\footnotetext{
6 Soerjono Soekanto, Efektivitasi Hukum Dan Peranan Sanksi, Bandung: Remadja Karya,1988, hlm. 60.

${ }^{7}$ Mahadi, , Laporan Hasil Pengajian Bidang Hukum Adat, BPHN, 1980. hlm. 61.

${ }^{8}$ Moh. Koesnoe, Catatan-Catatan Terhadap Hukum Adat Dewasa Ini, Surabaya: Airlangga University Press, 1979. hlm. 39.

${ }_{9}$ Alih bahasa dari buku Tom R. Tyler, 1990, Why People Obey The Law, Book Crafters, Library Of Congress Cataloging-in-Publication Data.
} 
kepada gampong untuk melakukan peradilan adat guna menyelesaikan sengketa/perselisihan secara adat. Hak dan kewenangan ini tegas diatur dalam UUPA, Qanun Aceh 9/2008, Qanun Aceh 10/2008, Pergub 60/2013, dan menjadi lebih operasional dengan adanya Surat Keputusan Bersama Gubernur, Kapolda Aceh, dan Majelis Adat Aceh tahun 2012. Sehingga, secara juridis formal, gampong sebagai MHA telah menjadi dasar kewenangan yang cukup legal dan kuat.

Kewenangan gampong dalam menyelesaikan perkara adat hanya terbatas pada 18 jenis sengketa/perselisihan, yang telah tegas dinyatakan dalam pasal 13 Qanun Aceh 9/2008 tentang Pembinaan Adat. Dalam pasal tersebut juga ditegaskan bahwa penyelesaian sengketa/perselisihan diselesaikan secara bertahap dan aparat penegak hukum harus memberi kesempatan terlebih dahulu agar agar sengketa/perselisihan diselesaikan terlebih dahulu secara adat di gampong. Ketentuan ini, bagi saya, bukan mengatur materi hukum adat, tetapi lebih mengukuhkan nilai dan materi hukum adat yang senyatanya memang eksis dalam masyarakat gampong.

Majelis peradilan adat gampong berupaya optimal untuk mendamaikan para pihak yang berselisih. Jadi putusannya bukan kalah - menang, tetapi damai dan sama-sama menang. Pentingnya dikembangkan peradilan adat oleh masyarakat hukum adat agar hal ini menjadi filter untuk meminimalisir jumlah perkara pada peradilan formal. Sehingga, keadilan hukum bisa lebih membumi, lebih dekat dicapai rakyat.

Efektifitas keberlakuan Qanun Nomor 9 Tahun 2008 dalam menyelesaikan perkara pidana adat di Kecamatan Kota Langsa belum efektif baik dari segi prosesnya maupun dari segi putusannya, yang membuat para pelaku tidak jera sehingga tidak merasa takut untuk mengulangi perbuatan tindak pidana adatnya.

\section{DAFTAR PUSTAKA}

Abdurrachman. 1980. Aneka Masalah Dalam Praktek Penegakan Hukum di Indonesia. Bandung: Penerbit Alumni. 
Abidin, Zaenal. 2007. Antara kebutuhan atau eksistensi. Bandung: Penerbit Alumni.

Amiruddin dan Zainal Asikin. 2004. Pengantar Metode Penelitian Hukum. Jakarta: Raja Grafindo Persada. 1998. Kamus Hukum. Jakarta: Ghalia Indonesia.

Departemen Pendidikan Nasional. 2008. Kamus Besar Bahasa Indonesia Pusat Bahasa. Jakarta: PT Gramedia Pustaka Utama.

Harahap, M. Yahya. 2005. Pembahasan Permasalahan dan Penerapan KUHAP Penyidikan dan Penuntutan. Jakarta: Sinar Grafika.

http://nadzzsukakamu, Eksistensi, wordpress, com/2010/07/29.

http://Google, Balance04, Blogspot, pengertian-tindak-pidana-penganiayaan, html.com/2011/01

http://id.wikipedia.org/wiki/Adat_istiadat

http://bahasa,cs,ui,ac,id/kbbi/kbbi,php?keyword=ringan\&varbidang=all\&vardiale $\mathrm{k}=$ all\&varragam=all\&varkelas=all\&submit=kamu

Kamisah. 1997. Kamus Lengkap Bahasa Indonesia. Surabaya:Penerbit Kartika, Surabaya.

Kartonomor, Sumariati. 1969. Apakah The Rule Of Law Itu. Bandung: Penerbit Alumni.

Koesnomore, Moh. 1979. Catatan-catatan Terhadap Hukum Adat Dewasa Ini, Surabaya: Airlangga University Press.

Marpaung, Leden. 2008. Proses Penanganan Perkara Pidana. Jakata: Sinar Grafika.

Peraturan Pemerintah Republik Indonesia nomormor 72 tahun 2005 tentang Desa

Qanun Nomormor 8 Tahun 2008 Tentang Pembinaan Kehidupan Adat dan Adat Istiadat

Sudarsonomor. 2007. Kamus Hukum. Jakarta: PT Rineka Cipta. 
Legalite : Jurnal Perundang Undangan dan Hukum Pidana Islam

Vol. 5 Edisi 1 2020, hal. 30-52

P-ISSN: 2527-9424 E-ISSN: 2614-7971

https://doi.org/10.32505/legalite.v5i1.1476

Tirtaamidjaja. 1955. Pokok-pokok Hukum Pidana. Jakarta: Fasco.

Undang-Undang Nomormor 32 tahun 2004 tentang Pemerintah Daerah

Undang-Undang Nomormor 11 tahun 2006 tentang Pemerintahan Aceh

W.J.S Poerwadarminta. 1994. Kamus Bahasa Indonesia. Jakarta. 